\title{
Effects of compost tea treatments on productivity of lettuce and kohlrabi systems under organic cropping management
}

\author{
Catello Pane, ${ }^{1}$ Assunta Maria Palese, ${ }^{2}$ Giuseppe Celano, ${ }^{2}$ Massimo Zaccardelli ${ }^{1}$ \\ ${ }^{1}$ Consiglio per la Ricerca e la Sperimentazione in Agricoltura, Centro di Ricerca per \\ l'Orticoltura, Pontecagnano (SA); ${ }^{2}$ Dipartimento delle Culture Europee e del Mediterraneo: \\ Architettura, Ambiente, Patrimoni Culturali, Università della Basilicata, Matera, Italy
}

\begin{abstract}
The use of compost tea (CT) is becoming interesting for applications in organic agriculture. CTs are oxygenated extracts of compost that give positive effects on the crops because contain bioactive molecules and microorganisms that improve plant growth and health. This study was carried out to evaluate the effects of CTs applied as foliar spray and drenching, respectively, on kohlrabi and lettuce cultivation. The CT tested here was originated by an aerated water-extraction of two artichoke and fennel composts. CT treatments considerably improved crop yields. CT, in fact, increased lettuce and kohlrabi commercial yields higher $24 \%$ and $32 \%$, respectively. Due to CT, the physiological and nutritional status of the plants increased, as noticed by foliar chlorophyll content assessment measured during crop cycles. The results provided encouraging indications about the practical application of CT in horticultural organic farming system.
\end{abstract}

Correspondence: Massimo Zaccardelli, Consiglio per la Ricerca e la Sperimentazione in Agricoltura, Centro di Ricerca per l'Orticoltura, via dei Cavalleggeri 25, I-84098 Pontecagnano (SA), Italy.

Tel.: +39.089 .386211 - Fax: +39.089 .384170 .

E-mail: massimo.zaccardelli@entecra.it

Key words: Brassica oleracea, disease control, Lactuca sativa, organic agriculture, plant biostimulation.

Acknowledgements: this research was supported by the BioCompost Project, funded by the PSR Campania Region 2007/2013 European funding programme (F.E.A.S.R., Measure 124).

Conference presentation: SIA XLII Congress, Reggio Calabria, 2013.

Received for publication: 20 February 2014

Revision received: 7 August 2014.

Accepted for publication: 25 August 2014.

(C) Copyright C. Pane et al., 2014

Licensee PAGEPress, Italy

Italian Journal of Agronomy 2014; 9:596

doi:10.4081/ija.2014.596

This article is distributed under the terms of the Creative Commons Attribution Noncommercial License (by-nc 3.0) which permits any noncommercial use, distribution, and reproduction in any medium, provided the original author(s) and source are credited.

\section{Introduction}

Vegetable crops are grown and consumed worldwide as source of fibres and nutraceutic compounds in human diets. Consumers tend to prefer organic foods compared to others, because they are perceived more nutritious and tasty. Moreover, food security reasons and environmental concerns are orienting the market and the growers toward sustainable agricultural systems, based on natural-deriving methods with the reduction of synthetic inputs. Compost is popular in organic agriculture because it replaces fertilizers and improves soil global fertility (Pane et al., 2013b). Relatively new compost-derived products, such as compost teas (CTs), although they are less common, show remarkable perspectives for diffusion and development among organic growers (Shaheen et al., 2013). They are gaining great interest in many country of North America (Hargreaves et al., 2009), Asia (Siddiqui et al., 2008) and, recently, scientific attention for these products started also to expand in Europe (Litterick et al., 2004). CTs are obtained by aerobic liquid extraction of quality composts from few hours to some days that essentially results in dissolved organic and inorganic molecules and useful microorganisms (Ingham, 1999). CTs can be counted among the most innovative organic source products developing in the field of crop management (Praveena Deepthi and Narayan Reddy, 2013). These compost-based formulates has been reported to produce beneficial effects when applied directly to the plants. Hargreaves et al. (2009) found that, for strawberry production, the foliar spray of CT was effective as soil application of compost. In addition, CTs were largely studied for their suppressive properties against disease development, due to antagonistic action of resident microbial community and/or improved plant defences (Pane et al., 2012). Nevertheless, only few workers assessed CTs foliar applications, while it is largely reported as a nutritional liquid solution for crop fertigation. CTs used in nitrogen-phosphorous-potassium fertilisers integration increased vegetative biomass and bioactive components production in the medicinal herb Centella asiatica (Siddiqui et al., 2011). Hormone-like molecules secreted by microbes, humic substances and nutritional elements contained in teas, are believed that may play a crucial role in the bio-stimulation of plants by upgrading their physiological status (Zaccardelli et al., 2012). Therefore, CTs may contribute at reducing the unsustainable use of chemical-based pesticides and fertilizers in the ecosystems. By taking into account that CTs are promising in sustainable horticultural crop management, further insights regarding their spray application in organic active systems, are still necessary. The present work was conducted to investigate the effects of a blend of two CTs from agricultural residue composts on agronomic performances of two vegetable productions, lettuce and kohlrabi, cultivated under greenhouse in a biological farm located in Southern Italy. 


\section{Materials and methods}

\section{On-farm compost-tea production}

Two composting piles were formed by mixing different materials according to the following composition: $\mathrm{Cl}=$ composted $78.0 \%$ artichoke, $20 \%$ woodchips and $2 \%$ mature compost starter; $\mathrm{C} 2=$ composted $43.5 \%$ artichoke, $23.5 \%$ fennel, $11.0 \%$ escarole residues, $20 \%$ woodchips and $2 \%$ mature compost starter (each value is expressed as dry weigh percentage). Raw piles were designed with an initial carbon/nitrogen ratio of about 30, in order to favour the composting switch on. The onfarm composting process was carried out in two parallel static piles of about $6 \mathrm{~m}^{3}$ in volume, under forced aeration for the first 45 days that included a thermophylic and a mesophilic phase, followed by a final curing period of about two months. The on-farm composting system was assembled by using tools currently available in a farm. In fact, mechanical aeration was provided by air injection through a net of tubes connected to a blower $(0.75 \mathrm{KW})$ that was periodically activated ( 5 min every $3 \mathrm{~h}$ ) with an electronic timer, and pile wetting was achieved through a PVC irrigation system, manually activated on demand (when relative humidity $<50 \%$ ). Composting temperatures were measured by thermo-sensors placed in the core of the pile at 15 $\mathrm{cm}$ from the pile bottom. Compost chemical analyses were performed as indicated in Pane et al. (2013a).

A compost extractor in liquid phase with a forced air blowing system, assembled using farmer facilities, was used to produce on farm aerated CTs in a 7-day fermentation cycle. Mechanical aeration was done by air injection through a submersed branched tube connected to a compressor. Automatic ventilation ( 3 min every $3 \mathrm{~h}$ ) was activated by an electromagnetic valve that received an impulse from an electronic timer. Compost, contained in a plastic bag with holes of $3 \mathrm{~mm}$ of diameter, was placed in a 50-L polyethylene container with a quantity of liquid ( $20 \mathrm{~L}$ of water) so to have a 1:5 v/v ratio. At the end of the process, after one week, CTs were filtered and mixed (50\% vol.) to prepare compost tea blend that then was stored at $4^{\circ} \mathrm{C}$ until used.

\section{Greenhouse trial}

Agronomic trials were carried out in 2012, under a greenhouse system in a loamy soil, at organic farm IdeaNatura located in Eboli (Salerno District, Campania Region, Italy). The experimental design was a randomized complete block with plot areas of about $5.40 \mathrm{~m}^{2}$ each, replicated three times. Two separate experiments were carried out in order to evaluate CT treatments, as aerial spray on kohlrabi cultivation and, as soil drenching, on lettuce. Lettuce cv. Palomis (Lactuca sativa var. gentilina) and kohlrabi cv. Volturno (Brassica oleracea var. gongylodes) plantlets were transplanted on November $16^{\text {th }}$ and $26^{\text {th }} 2012$, respectively, both on single rows, at distances of $0.30 \times 0.30 \mathrm{~m}$, so to have a density of about 11 plants $\mathrm{m}^{-2}$. Blended CT, water diluted $10 \%$ vol., was weekly applied by spraying aerial parts on kohlrabi and, as drenching $\left(0.5 \mathrm{~L} \mathrm{~m}^{-2}\right)$, at the base of lettuce plants. Plants vegetative and phytosanitary status were monitored during the whole cycle by direct clinical observations. The physiologic-nutritional status of the plants, instead, was followed measuring the clorophyll concentration in the last leaf completely developed, using SPAD-meter (Konica Minolta, Inc., Tokyo, Japan) on ten different plants. At harvesting, occurred on March $22^{\text {nd }} 2013$ for kohlrabi (20 plants on $1.80 \mathrm{~m}^{2}$ assay area) and

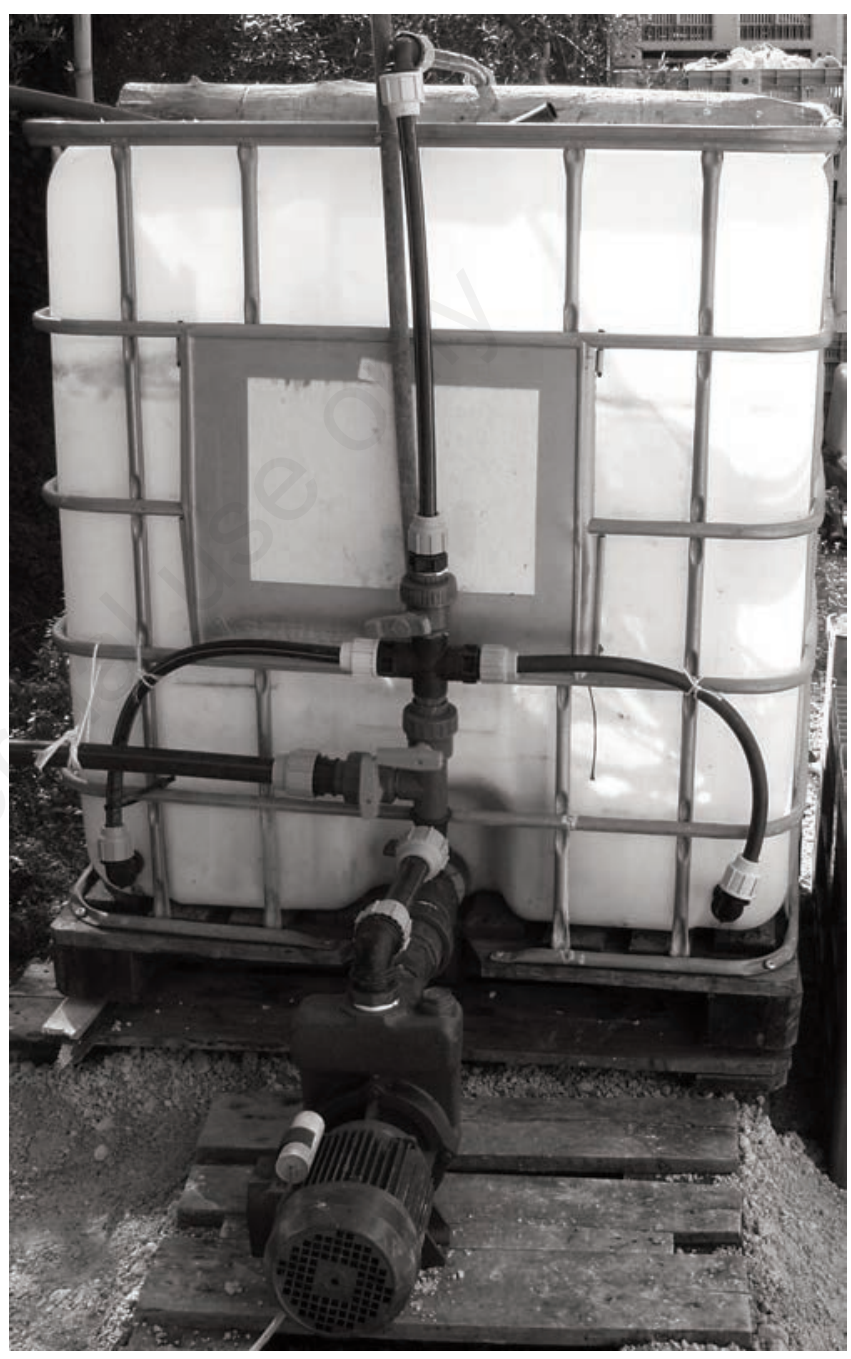

Figure 1. Liquid-based blowing system for the on-farm production of aerated compost tea.

Table 1. Main chemical quality characteristics of the composts used to produce compost tea.

\begin{tabular}{|c|c|c|c|c|c|c|c|c|c|c|c|c|c|c|}
\hline \multirow[b]{2}{*}{ Composts } & \multicolumn{14}{|c|}{ Chemical features } \\
\hline & $\mathrm{pH}$ & $\begin{array}{c}\mathrm{EC} \\
\left(\mathrm{mS} \mathrm{cm} \mathrm{cm}^{-1}\right)\end{array}$ & $\begin{array}{l}\mathrm{N} \\
(\%)\end{array}$ & $\begin{array}{l}\text { P } \\
(\%)\end{array}$ & $\begin{array}{c}K \\
(\%)\end{array}$ & $\begin{array}{c}\mathrm{Ca} \\
(\%)\end{array}$ & $\begin{array}{l}\mathrm{Mg} \\
(\%)\end{array}$ & $\begin{array}{l}\mathrm{Na} \\
(\%)\end{array}$ & $\begin{array}{c}\mathrm{Mn} \\
(\mathrm{ppm})\end{array}$ & $\begin{array}{c}\mathrm{Cd} \\
(\mathrm{ppm})\end{array}$ & $\begin{array}{c}\mathrm{Cr} \\
(\mathrm{ppm})\end{array}$ & $\begin{array}{c}\mathrm{Cu} \\
(\mathrm{ppm})\end{array}$ & $\begin{array}{c}\mathrm{Pb} \\
(\mathrm{ppm})\end{array}$ & $\begin{array}{c}\mathrm{Zn} \\
(\mathrm{ppm})\end{array}$ \\
\hline $\mathrm{C}_{1}$ & 9.01 & 6.99 & 1.73 & 0.023 & 4.28 & 8.30 & 1.78 & 0.38 & 307.66 & 0.38 & 20.69 & 21.01 & 13.45 & 70.50 \\
\hline $\mathrm{C}_{2}$ & 9.48 & 6.60 & 1.58 & 0.020 & 5.10 & 6.71 & 0.93 & 0.50 & 322.86 & 0.43 & 16.70 & 32.67 & 15.51 & 68.15 \\
\hline Legal limits & & & & & & & & & & $<1.5$ & $<100$ & $<150$ & $<140$ & $<500$ \\
\hline
\end{tabular}

EC, electrical conductivity; N, nitrogen; P, phosphorus; K, potassium; Ca, calcium; Mg, magnesium; Na, sodium; Mn, manganese; Cd, cadmium; Cr, chromium; Cu, copper; Pb, lead; Zn, zinc. 
February $7^{\text {th }} 2013$ for lettuce (12 plants on $1.08 \mathrm{~m}^{2}$ assay area), the main productive traits were assessed. Descriptive statistics were performed by one-way analysis of variance to test differences in production data.

\section{Results and discussion}

Three-month on-farm composting of agricultural residues of artichoke and fennel provided two reliable composts with appreciable content of macro and microelements, as showed in Table 1. Bioactivity of these organic matters has been previously investigated on Lepidium sativum seedlings, on which they showed mainly suppressive properties (Pane et al., 2013a). Here, they were chosen to produce CTs potentially applicable under organic agriculture managing. Then, each of these composts were water-extracted in a farming blower system (Figure 1), blended, diluted and used on the plants.

CT treatments affected agronomic performances of the two crops. They, in fact, improved significantly both lettuce and kohlrabi productions. In detail, total and commercial yield of lettuce in the treated plots were, respectively, higher $6 \%$ and $24 \%$ than that of the control plots (Figure 2). Head fresh weight of the treated lettuce was $0.45 \mathrm{~kg}$, while that of the control was $0.43 \mathrm{~kg}$. For kohlrabi, instead, CT treatments induced an improvement of total and commercial production that were higher $26 \%$ and $32 \%$, respectively, than that of the control plots (Figure 2). In addition, single head fresh weight of the treated kohlrabi was 0.89 $\mathrm{kg}$, while that of the control was $0.66 \mathrm{~kg}$. In absence of any particular phytosanitary problem, since plants in the experimental sites developed normally, the productive data indicated a potential bio-stimulation activity played by the organic formulate on the plants. CT treatments, in addition, affected plant physiological status as confirmed by SPAD analysis of leaf chlorophyll content, carried out during the whole cropping cycle that, on average, was higher than controls in treated plants (Figure 3). This parameter is also informative about the nutritional plant status. Siddiqui et al. (2008) found a positive relation between the increases of total chlorophyll content induced by vegetal compost extracts and the enhanced photosynthesis rate observed in Abelmoschus esculentus. In these conditions, plants can over-induce carbohydrates synthesis and store precious energy for the following vegetative development. In our work, SPAD temporal patterns showed that chlorophyll content in CT treated plants exceeded, in initial phases, those of the control ones. Naidu et al. (2013) reported that microbial-enriched CTs, inciting a global physiological response in treated muskmelon plants, including increases in chlorophyll content, caused stimulation of flowering, growth, yield and quality. CT's stimulatory effects may be also ascribed to its humic component (Nardi et al., 2002). The described positive effects of compost-based treatments on plant growth and physiology has been largely associated to hormonal activity of CT, due to a specific group of dissolved molecules. Actually, some of these substances, with indefinite origins, including gibberellins (Pant et al., 2012), indoleacetic acid (Ertani et al., 2013) and cytokinins (Zhang et al., 2013), have been occasionally identified in highly bioactive teas. Bernal-Vicente et al. (2008) reported significant increases in melon biomass produced by root-treatments of nursery plants with compost extracts carrying auxinic and cytokininic-like compounds. Due to an assessed auxin-like activity, humic-like substances from compost extracts promoted cucumber growth and increased chlorophyll content in leaves (Xu et al., 2012). The present research showed that the CT from agricultural composts might be effective in stimulation of crop productivity. Results encourage the practical use of CT in organic farming. However, future applicative experiments will be useful to get more knowledge about CT performances.

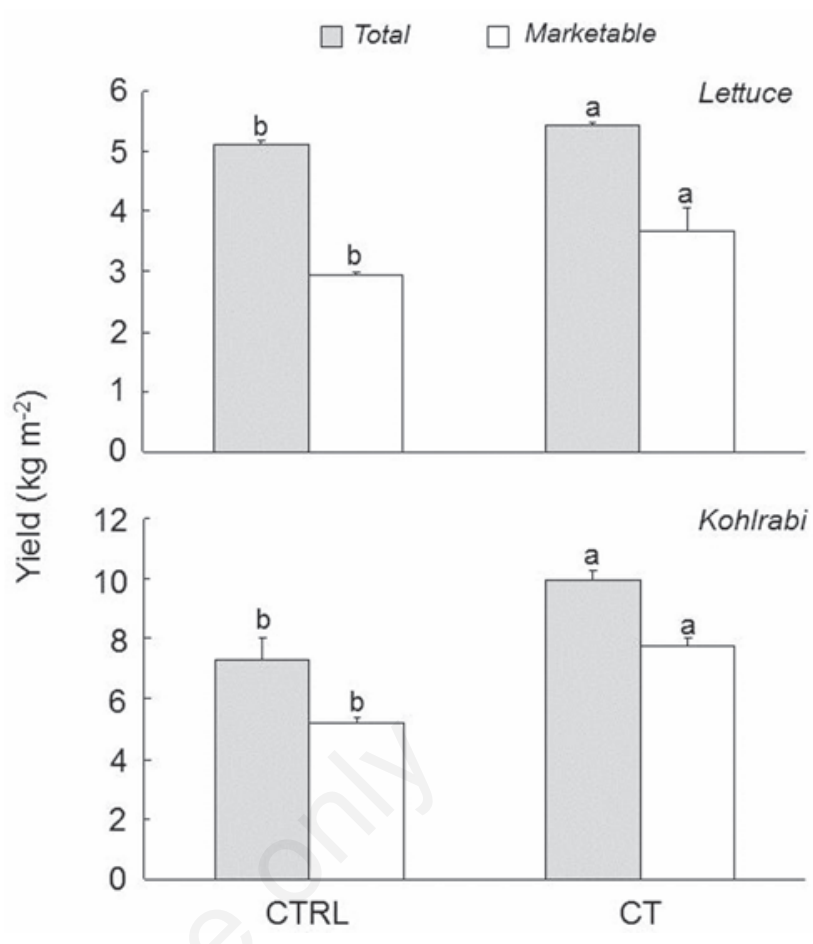

Figure 2. Effects of compost tea (CT) treatments on agronomic performances of lettuce and kohlrabi cropping systems in comparison with untreated control (CTRL). Different letters indicate significant differences (analysis of variance, Duncan's test, $\mathbf{P} \leq 0.05)$.

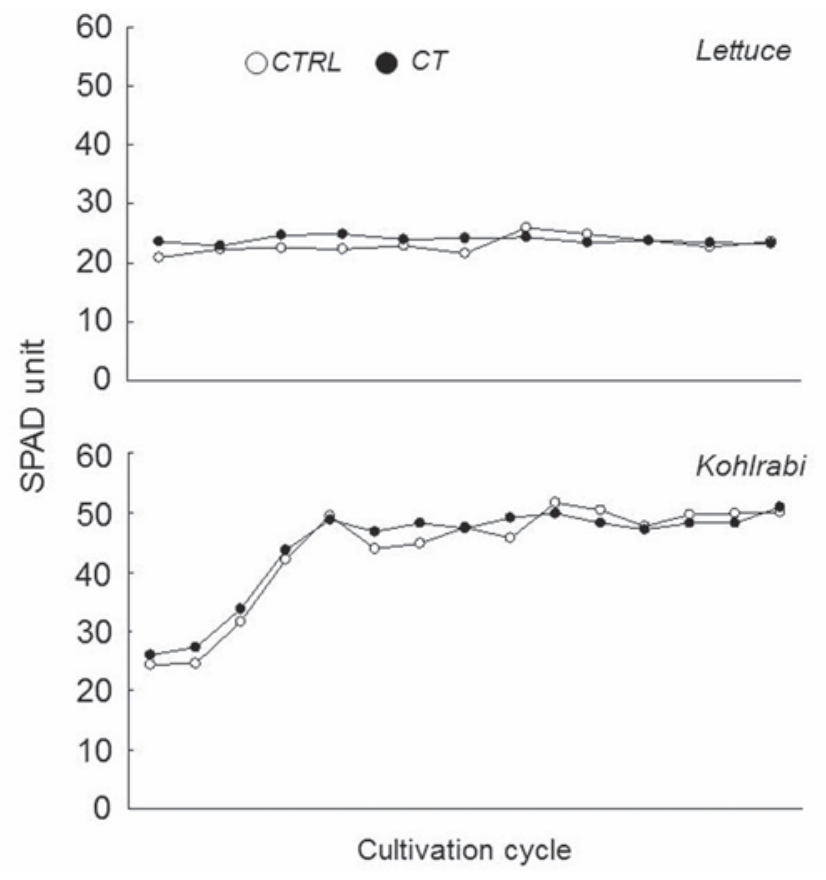

Figure 3. Effect of compost tea (CT) on temporal trend of physiologic-nutritional lettuce and kohlrabi status evaluated by assessing SPAD unit clorophyll leaf content in comparison with untreated control (CTRL). 


\section{Conclusions}

A number of reports have shown that CTs are able to protect plants against biotic stresses caused by pathogenic factors. Conversely, stimulatory effects of CTs on plant growth and productivity have been previously less investigated although, lately, they are receiving great attention. Here, field trials indicated the potential of this organic formulate to induce bio-stimulation effects by enhancing productivity of the plants. These functions played by CTs, in fact, potentially can have a great impact on sustainable agricultural systems. They may determine a more efficient growth of the plants, reducing dependence from external inputs, such as pesticides and fertilizers. Therefore, advances on this topic could increase the potential for diffusion and practical applications of these organic formulates. However, since underlying mechanisms of action are still largely unknown, further studies are still necessary.

\section{References}

Bernal-Vicente A, Ros M, Tittarelli F, Intrigliolo F, Pascual JA, 2008. Citrus compost and its water extract for cultivation of melon plants in greenhouse nurseries. Evaluation of nutriactive and biocontrol effects. Biores. Technol. 99:8722-8.

Ertani A, Pizzeghello D, Baglieri A, Cadili V, Tambone F, Gennari M, Nardi S, 2013. Humic-like substances from agro-industrial residues affect growth and nitrose assimilation in maize (Zea mays L.) plantlets. J. Geochem. Explor. 129:103-11.

Hargreaves JC, Sina Adl M, Warman PR, 2009. Are compost teas an effective nutrient amendment in the cultivation of strawberries? Soil and plant tissue effects. J. Sci. Food Agric. 89:390-7.

Ingham ER, 1999. What is compost tea? Part I . BioCycle 40:74-5.

Litterick AM, Harrier L, Wallace P, Watson CA, Wood M, 2004. The Role of uncomposted materials, composts, manures, and compost extracts in reducing pest and disease incidence and severity in sustainable temperate agricultural and horticultural crop production - a review. Crit. Rev. Plant Sci. 23:453-79.

Naidu Y, Meon S, Siddiqui Y, 2013. Foliar application of microbialenriched compost tea enhances growth, yield and quality of muskmelon (Cucumis melo L.) cultivated under fertigation system.
Sci. Hort. 159:33-40.

Nardi S, Pizzeghello D, Muscolo A, Vianello A, 2002. Physiological effects of humic substances on higer plants. Soil Biol. Biochem. 34:1527-36.

Pane C, Celano G, Villecco D, Zaccardelli M, 2012. Control of Botrytis cinerea, Alternaria alternata and Pyrenochaeta lycopersici on tomato with whey compost-tea applications. Crop Prot. 38:80-6.

Pane C, Piccolo A, Spaccini R, Celano G, Villecco D, Zaccardelli M, 2013a. Agricultural waste-based composts exhibiting suppressivity to diseases caused by the phytopathogenic soil-borne fungi Rhizoctonia solani and Sclerotinia minor. Appl. Soil Ecol. 65:43-51.

Pane C, Villecco D, Zaccardelli M, 2013b. Short-time response of microbial communities to waste compost amendment of an intensive cultivated soil in Southern Italy. Comm. Soil Sci. Plant Anal. 44:2344-52.

Pant AP, Radovich TJK, Hue NV, Paull RE, 2012. Biochemical properties of compost tea associated with compost quality and effects on pak choi growth. Sci. Hort. 148:138-46.

Praveena Deepthi K, Narayan Reddy P, 2013. Compost teas - an organic source for crop disease management. Int. J. Innov. Biol. Res. 2:51-60.

Shaheen AM, Rizk FA, Sawan OM, Bakry M0, 2013. Sustaining the quality and quantity of onion productivity throughout complementrity treatments between compost tea and amino acids. Middle East J. Agric. Res. 2:108-15.

Siddiqui Y, Islam TM, Naidu Y, Meon S, 2011. The conjunctive use of compost tea and inorganic fertiliser on the growth, yield and terpenoid content of Centella asiatica (L.) urban. Sci. Hort. 130:289-95.

Siddiqui Y, Meon S, Ismail R, Rahmani M, Ali A, 2008. Bio-efficiency of compost extracts on the wet rot incidence, morphological and physiological growth of okra (Abelmoschus esculentus [(L.) Moench]). Sci. Hort. 117:9-14.

Xu DB, Wang QJ, Wu YC, Yu GH, Shen QR, Huang QW, 2012. Humic-like substances from different compost extracts could significantly promote cucumber growth. Pedosphere 22:815-24.

Zaccardelli M, Pane C, Scotti R, Palese AM, Celano G, 2012. Use of compost-teas as biopesticides and biostimulants in orticulture. Italus Hort. 19:17-28.

Zhang H, Tan SN, Wong WS, Ng CYL, Teo CH, Ge L, Chen X, Yong JWH, 2013. Mass spectrometric evidence for the occurrence of plant growth promoting cytokinins in vermicompost tea. Biol. Fert. Soils 50:401-3. 